\title{
A Case of Squamous Cell Carcinoma in Situ of the Middle Ear
}

\author{
Byung Whoo Park and Moo Jin Baek (D) \\ Department of Otorhinolaryngology, Inje University Haeundae Paik Hospital, Busan, Korea
}

\section{중이강 내 발생한 상피내암 1예}

박 병 후·백 무 진

인제대학교 해운대백병원 이비인후과학교실

\author{
Received October 8, 2018 \\ Revised November 12, 2018 \\ Accepted November 21, 2018 \\ Address for correspondence \\ Moo Jin Baek, MD, PhD \\ Department of Otorhinolaryngology, \\ Inje University \\ Haeundae Paik Hospital, \\ 875 Haeun-daero, Haeundae-gu, \\ Busan 48108, Korea \\ Tel $+82-51-797-2290$ \\ Fax $+82-51-797-2304$ \\ E-mail mjbaek@paik.ac.kr
}

\begin{abstract}
Malignancy of the middle ear is rare and its estimated incidence is 0.18 cases per million people in the US, with its most common type being squamous cell carcinoma. Squamous cell carcinoma in situ is thought to be a precursor to squamous cell carcinoma, which is extremely rare in the middle ear. The pathology reports of squamous cell carcinoma have not been wellcharacterized as it has not been reported to date in Korea. Here, we report a case of squamous cell carcinoma in situ of the middle ear in a 66-year-old man, who presented with otorrhea and tympanic membrane perforation.
\end{abstract}

Korean J Otorhinolaryngol-Head Neck Surg 2019;62(9):529-32

Key Words Middle ear · Carcinoma in situ.

\section{서 론}

중이강 내 악성종물은 미국에서 100 만명당 0.18 명 정도의 유병률을 보일 정도로 흔치 않은 질환이다. ${ }^{1)}$ 이러한 중이강 내에 발생하는 악성종물 중 편평세포상피암(squamous cell carcinoma)이 가장 흔하며, 55.9 62.8\%의 비중을 차지한 다. ${ }^{1,2)}$ 아직까지 정확한 원인과 병태생리는 밝혀져 있지 않지 만 많은 연구들에서 만성 중이염이 위험인자로서 작용할 수 있다고 보고하고 있다. ${ }^{3)}$ 편평세포상피내암(squamous cell carcinoma in situ)은 신체 어느 부위에서나 발생할 수 있으며, 외이도에 발생한 증례는 보고된 바 있으나, ${ }^{4)}$ 중이강 내에 발 생하는 경우는 드물며, 아직까지 국내에서 알려진 바는 없다. 이에 저자들은 영상학적 검사 및 이학적 소견에서 만성 중 이염으로 좌측 고실성형술 중 두꺼워진 고실 중앙 갑각부의

This is an Open Access article distributed under the terms of the Creative Commons Attribution Non-Commercial License (https://creativecommons.org/licenses/by-nc/4.0) which permits unrestricted non-commercial use, distribution, and reproduction in any medium, provided the original work is properly cited.
점막을 제거 한 후 편평세포상피내암으로 진단된 1예를 경험 하여 문헌고찰과 함께 보고하는 바이다.

\section{증 려}

66세 남자 환자로 천식 과거력 이외 특이 병력 없는 분으로 30년 전부터 반복되는 좌측 이루로 좌측 만성 중이염 진단 하에 수술 권유 받아 본원으로 내원하였다. 노란색 이루 이 외에 청력저하, 어지러움 등의 증상은 없었으며, 가족력에서 특이사항은 없었고, 전신상태는 양호하였다. 이 내시경 검사 상 좌측 고막의 전하부에 천공소견(Fig. 1)이 관찰되었으며, 노란색 이루가 관찰되었다.

혈액검사, 생화학검사, 흥부 방사선검사 등 술전 검사는 정 상이었으며, 술전 순음청력검사 상 좌측 기도청력검사 역치는 $36 \mathrm{~dB}$, 골도 청력검사 역치는 $24 \mathrm{~dB}$ 이었다(Fig. 2). 측두골 전 산화단층촬영에서 좌측 측두골의 중이강과 유양동 부위에 연부조직 증가 및 유돌봉소의 소실과 경화변성 소견이 보였으 
며, 이소골 및 경판, 골성미로의 침범은 보이지 않았다(Fig. 3).

이에 저자들은 이학적 검사 및 영상학적 검사를 고려하여 전신마취하에 좌측 고실 성형술 및 폐쇄형 유양동 삭개술을

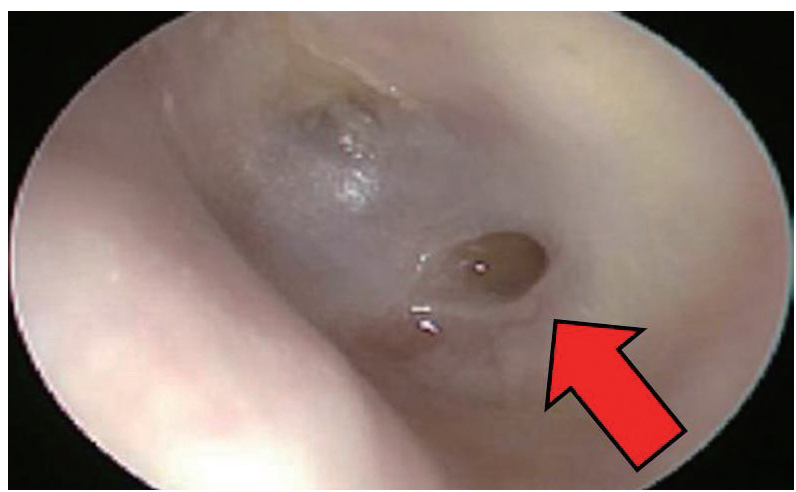

Fig. 1. Preoperative otoscopy findings in the patient. At otoscopic examination, anterior inferior small perforation with yellowish discharge was observed at left tympanic membrane (arrow: perforated tympanic membrane).
계획하였다. 수술 현미경을 통하여 확인한 좌측 고막은 매우 두껍고 전하방에 천공이 관찰되었으며, 갑각 주변 중이 점막 은 비교적 두꺼워져 있었으며 특히 갑각 주변의 점막이 약간 의 종창과 함께 두껍고 질긴 소견이어서 이를 포함한 주위의 점막을 제거하였으며, 이관 입구부/전방/하방의 정상적인 점 막은 보존하였다. 고실 후방부 안면신경와 및 고실동의 점막 이 육아종을 형성하고 있어 제거하였고 분비물도 관찰되었 으며 남아 있는 점막 상태는 양호하였다. 이소골 침골과 등골 사이 비후된 점막으로 일부 연결이 되어 있는 부위는 제거하 였고 이소골 상태 및 가동성도 양호하였다. 유양돌기동의 내 측 및 외측에는 두꺼운 육아종 조직이 존재하였으며 이는 유 양동구까지 퍼져있어 조직검사 시행 후 남김없이 제거하였고, 추골의 내측에 측두근막을 이식 후, 중이강과 외이도를 패킹 후 수술을 종결하였다.

수술 후 제거된 중이강 내 갑각 주변 비후된 점막에서 시 행한 조직검사의 절편은 $0.4 \times 0.3 \times 0.3 \mathrm{~cm}$ 크기의 회색과 분

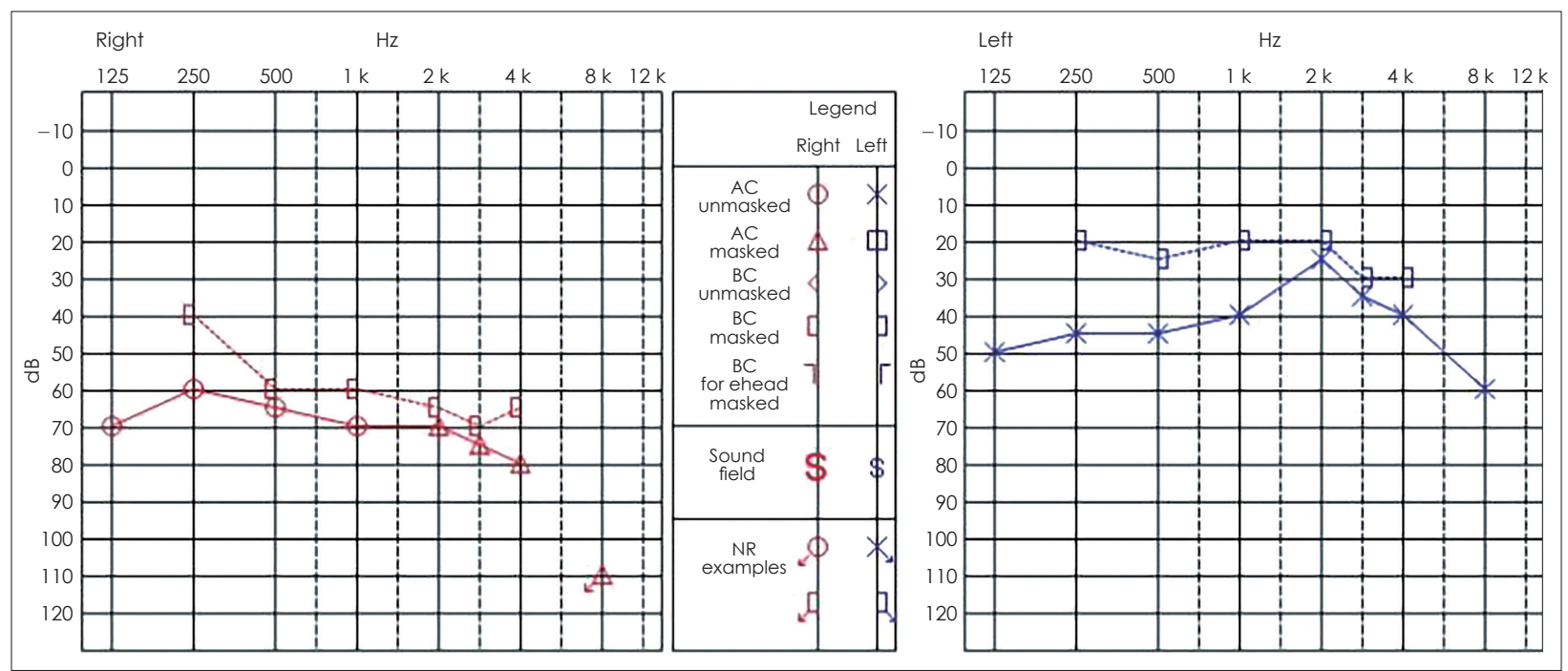

Fig. 2. Preoperative pure tone audiometry findings in the patient. At audiometry examination, air conduction threshold was $36 \mathrm{~dB}$ and bone conduction threshold was $24 \mathrm{~dB}$. Air-bone conduction gap was $12 \mathrm{~dB}$. AC: $36 \mathrm{~dB}, \mathrm{BC}: 24 \mathrm{~dB}, \mathrm{~A}-\mathrm{B}$ gap: $12 \mathrm{~dB}$.
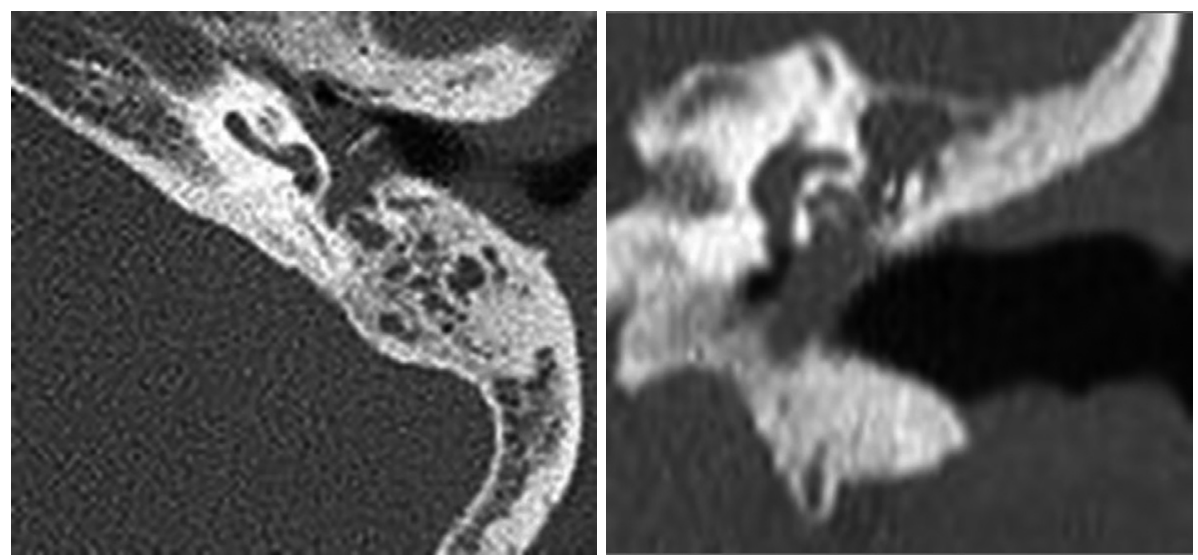

Fig. 3. Preoperative temporal bone computed tomography findings in the patient. Abnormal soft tissue density was seen in the left middle ear, but there was no evidence of temporal bone or ossicular destruction. 
Fig. 4. Histopathologic examinations. The tumor cells appear highly atypical, showing large, hyperchromatic nuclei and cell keratinization. Basement membrane remains intact (H\&E, $\times 200)(A)$. The tumor cells are positive in atypical cells for ki 67 gene expression $(H \& E, \times 200)(B)$. H\&E: hematoxylin and eosin.
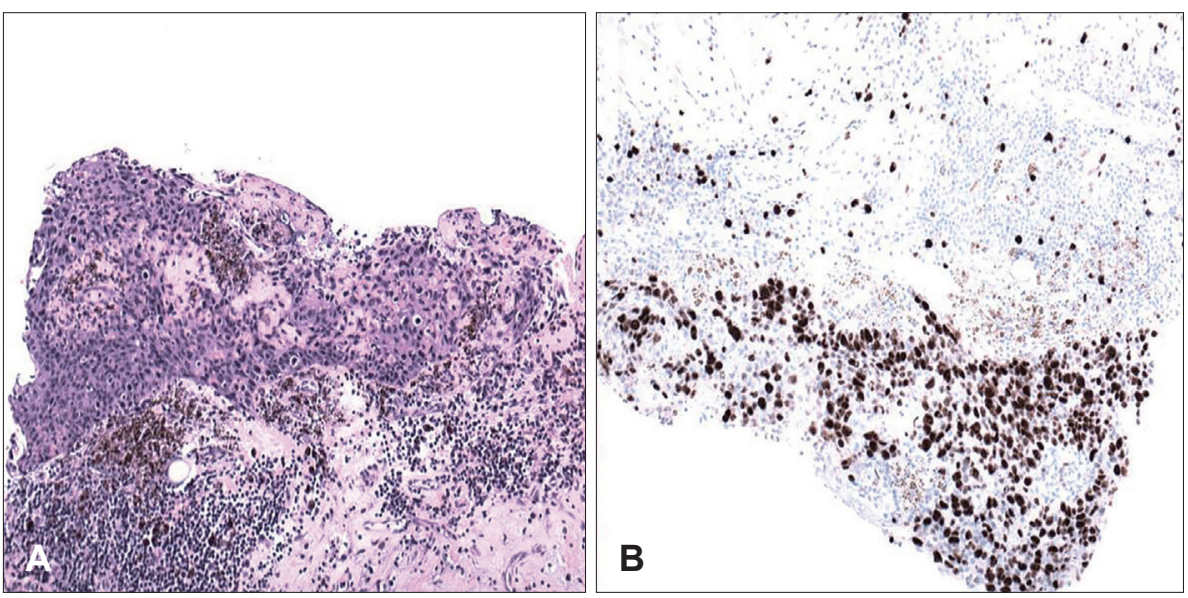

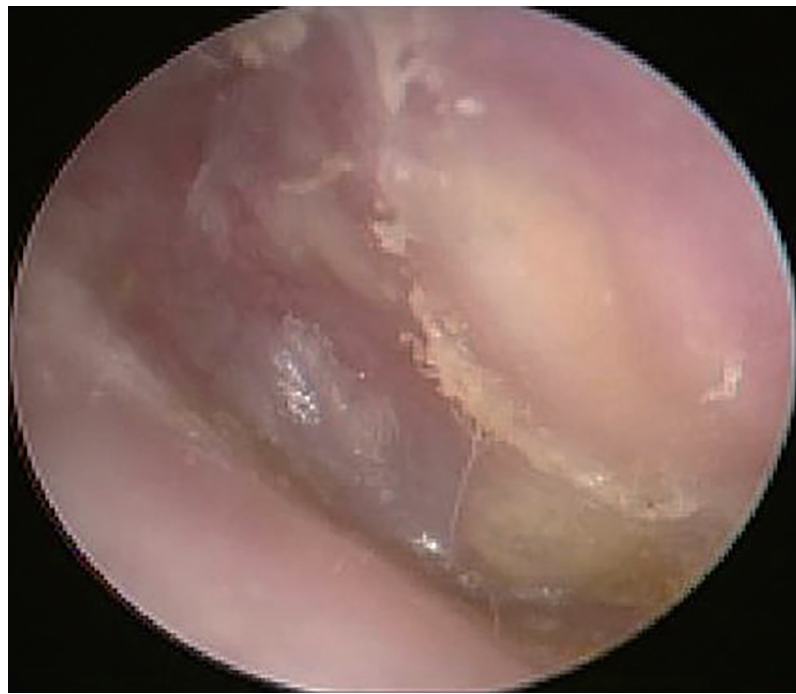

Fig. 5. Postoperative otoscopy findings after 1 year in the patient. At otoscopic examination, perforation was not observed and the drum was well healed state without any discharge.

홍빛의 조직이었으며, 표피의 불규칙한 배열과 다핵각질세포 가 관찰되었고 과립층 소실 및 기저세포막은 침범되지 않은 소견을 보였으며 유사분열의 수는 증가되어 있었다. 면역조직 화학염색에서는 p53(tumor suppressor protein) 음성반응을 보였으며, ki67(cell proliferation related protein)는 비전형 편평세포에서 양성반응을 보였다(Fig. 4). 최종적으로 편평세 포상피내암으로 진단 되었다. 기타 고실내에서 시행한 육아 종 및 점막조직과 유양돌기동 내에서 시행한 조직검사에서는 최종적으로 만성염증소견으로 진단 되었다.

수술후 2주째 패킹을 교체하였으며, 고막의 천공소견은 호 전 되었으며(Fig. 5), 1년째 외래통원치료 통하여 이경검사 및 증상에 대한 추적관찰 중이며, 수술 후 positron emission tomog-raphy 영상 등을 시행하고자 하였으나 점막 내 병변이 라 적응이 되지 않고 나타날 가능성이 없다는 설명을 듣고, 중이내 종물이나 이상 소견이 발견 시 컴퓨터단층촬영 및 자
기공명촬영 후 고실 내 조직 검사를 시행할 예정으로 경과 관찰 중이다.

\section{고 찰}

중이강 내 발생한 편평세포암의 증상은 크기나 위치에 따 라 다양하며 지속적인 이루, 이통, 청력저하, 안면신경마비 등 과 같은 증상이 발생할 수 있으며, 안면 마비와 돌발성 난청 등의 증상은 편평세포암의 말기에 종종 발견된다. ${ }^{1 .}$ 중이강은 측두골의 추체부에 위치하여 혈액 및 림프순환이 부족하여 다른 두경부암에 비해 전이가 적은 편이다.1) 따라서 중이염 환자에서 중이강 내의 암을 조기진단하기 위해서는 이루, 이 통 등의 이과적 증상의 최근 변화에 주목할 필요가 있다. ${ }^{5)}$ 진단을 위한 영상검사는 측두골 전산화 단층 촬영 및 자기공 명영상에서 골미란 및 연조직 종물 소견이 보일 수 있으나, 종 물의 특성을 정확히 반영하지 못하기 때문에, 수술 현미경을 통한 종물의 확인과 국소 조직검사가 진단에 있어 중요하다. ${ }^{\circ}$ 본 증례 또한 이학적 검사 및 영상학적 검사에서 만성 중이염 진단하에 고실성형술 및 폐쇄형 유양동삭개술을 시행 하였 지만, 술 중 수술현미경을 통한 갑각 부위 비후성 변화를 보 인 중이 점막의 확인 및 국소 조직검사를 통해 편평세포상피 내암으로 진단되었다. 측두골 내 암종의 발병률은 매우 드물 며 모든 두경부 영역 종물 중 $0.2 \%$ 이하의 빈도를 보이며, 외 이도 및 중이강 내의 암은 더욱 더 드물다." 가장 흔한 조직형 은 편평세포상피암이며 편평세포상피내암은 편평세포상피암 의 전구단계로서 3 8\%의 비율로 편평세포상피암으로 진행 할수 있다. ${ }^{8)}$ 중이강 내 발생하는 편평세포상피암의 경우 원 격 전이 및 임파선 전이가 발생하는 경우는 적으나, 5년 생존 율이 $32 \%$, 평균 생존율이 18.3 개월로 예후가 나쁜 편이다. ${ }^{9}$ 사망의 원인은 대부분 편평세포상피암과 관련 있으며,") 재발 률은 국소(local) $20.5 \%$, 지역(regional) $5.5 \%$, 원격(distant) 
$6.3 \%$ 이며, ${ }^{10)} 5$ 년 생존률을 비교했을 때 재발 및 전이가 있을 시에 생존률이 나쁜 편이다. ${ }^{11)}$ 경계 음성을 통한 완전한 수술 적 절제가 가장 좋은 치료방법이며, 보조적인 방사선 치료가 추가될 수 있으나, 방사선 치료의 효능은 현재까지 논란이 있 다.1,12) 수술은 완전한 블록(enbloc) 절제술, 측면 측두골 절제 술, 완전 측두골 절제술 등의 방법이 있다.

본 증례에서는 술 중 시행한 검사상 편평세포상피암의 전단 계인 편평세포상피내암이 진단되었으며, 편평세포상피내암의 경우, 일반적으로 광범위 절제술 만으로 치료가 충분하다고 알려져 있다. ${ }^{13)}$ 고실 내 갑각 부위의 비후성 변화를 보인 점 막은 정상 점막을 포함하여 남김없이 절제하였으며, 재발 및 악성 변화의 가능성을 고려하여 외래 통원치료를 통한 경과 관찰 중이다.

중이강 내 발생한 악성 종양은 매우 드물고, 만성 중이염과 밀접한 연관이 있으며, 완전 절제 및 경우에 따라 부가적인 방사선치료가 필요할 수 있다. 하지만 만성 중이염 및 기타 종 양과 감별하지 못할 경우 완전한 절제술을 시행하지 않을 수 있어 이경 및 영상검사, 국소 조직학적 소견을 종합하여 진단 해야 하며, 상피내암이 진단될 시 상피암으로 진행되지 않도 록 조기에 완전한 절제술을 시행하는 것이 중요할 것으로 생 각된다.

\section{ORCID}

Moo Jin Baek

$$
\text { https://orcid.org/0000-0002-0070-8311 }
$$

\section{REFERENCES}

1) Feng L, Jin A, Dai B, Li Y, Guo Y, Wang D, et al. Outcomes of 18 cases with squamous cell carcinoma of middle ear who underwent both surgery and post-operative radiotherapy. Acta Otolaryngol 2016;136(2):141-3.

2) Gurgel RK, Karnell LH, Hansen MR. Middle ear cancer: A populationbased study. Laryngoscope 2009;119(10):1913-7.

3) Jia X, Liang Q, Chi F. Treatment and outcome of middle ear cancer. Eur Arch Otorhinolaryngol 2014;271(10):2675-80.

4) Lee KC, Higgins HW 2nd, Lajevardi N, Cruz AP, Dufresne RG Jr. Characteristics of squamous cell carcinoma in situ of the ear treated using Mohs micrographic surgery. Dermatol Surg 2012;38(12): 1951-5.

5) Agada FO, Gnananandha C, Wichham M. Squamous cell carcinoma of the middle ear: Case report and literature review. Ann Afr Med 2004;3:90-2.

6) Lloyd GA, Phelps PD. The investigation of petro-mastoid tumours by high resolution CT. Br J Radiol 1982;55(655):483-91.

7) Ugumori T, Hyodo J, Hato N, Gyo K. Survival in primary carcinoma of the external and middle ear is strongly dependent on stage at diagnosis. Int J Otorhinolaryngol Head Neck Surg 2013;2(6):221-7.

8) Cox NH, Eedy DJ, Morton CA. Guidelines for management of Bowen's disease. Br J Dermatol 1999;141(4):633-41.

9) Brant JA, Eliades SJ, Chen J, Newman JG, Ruckenstein MJ. Carcinoma of the middle ear: A review of the national cancer database. Otol Neurotol 2017;38(8):1153-7.

10) Morris LG, Mehra S, Shah JP, Bilsky MH, Selesnick SH, Kraus DH. Predictors of survival and recurrence after temporal bone resection for cancer. Head Neck 2012;34(9):1231-9.

11) Yin $M$, Ishikawa $K$, Honda $K$, Arakawa $T$, Harabuchi $Y$, Nagabashi $T$, et al. Analysis of 95 cases of squamous cell carcinoma of the external and middle ear. Auris Nasus Larynx 2006;33(3):251-7.

12) Shen W, Sakamoto N, Yang L. Prognostic models to predict overall and cause-specific survival for patients with middle ear cancer: A population-based analysis. BMC Cancer 2014;14:554.

13) Shu MT, Lin HC, Yang CC, Chang KM. Squamous cell carcinoma in situ of the external auditory canal. J Laryngol Otol 2006;120(8): 684-6. 